\title{
Molecular analysis of Continuous Plankton Recorder samples, an examination of echinoderm larvae in the North Sea
}

\author{
Richard R Kirby*‡ and John A. Lindley ${ }^{\dagger}$ \\ *Royal Society University Research Fellow, School of Biological Sciences, University of Plymouth, Drake Circus, \\ Plymouth, PL4 8AA, UK. †Sir Alister Hardy Foundation for Ocean Science, Citadel Hill, The Hoe, Plymouth, PL1 2PB, \\ UK. ‡Corresponding author, e-mail: r.kirby@mba.ac.uk
}

\begin{abstract}
Analysis of the biological time series of plankton samples collected by the Continuous Plankton Recorder (CPR) in the North Atlantic and North Sea has shown a regime shift in the plankton in this region. Both the distributions of planktonic organisms and their timing of occurrence in the seasonal cycle have changed and these changes appear to reflect global warming. In the North Sea the planktonic larvae of echinoderms have shown a recent dramatic increase in both relative and absolute abundance and their seasonal peak of occurrence has advanced by 47 days. The identity of the echinoderm larvae involved in this change has, however, remained equivocal. The small size of many organisms like echinoderm larvae combined with incomplete taxonomic keys hinders their visual identification and their fragility often means that useful morphological features are damaged during sampling by the CPR. Here, using new molecular methods applied to CPR samples, we show that planktonic larvae of the benthic Echinocardium cordatum dominate the North Sea plankton. We argue that since this species benefits from mild winters and warmer waters their numerical increase in the plankton is consistent with recent climatic changes that appear to be affecting the wider ecology of this region.
\end{abstract}

\section{INTRODUCTION}

The marine plankton are key components of the marine ecosystem and central in the global carbon cycle. Planktonic organisms are difficult to study due to their geographical location however; so many aspects of their biology remain unresolved. For example, the prevalence of cryptic species in the plankton is unknown (e.g. Lee, 2000; Caudill \& Bucklin, 2004) and many larval forms are undescribed or the larvae not linked to the adult. There are only larval descriptions for approximately one third of over 170 species of decapod crustacean in the Pacific north-west of the United States (Puls, 2001). When larvae are described from the plankton it can still be very difficult to link them to the appropriate adult organism. It took 22 years before an anomalous brachyuran zoea larva was identified with any certainty as Dorhynchus thomsoni (Williamson, 1982). When larval descriptions are available, specific identifications on morphological criteria may still be impracticable or impossible (e.g. Clark, 1984). All these problems contribute to a paucity of ecological work in which meroplankton are iden- tified specifically rather than being recorded at higher taxonomic level (Family, Order, Class or Phylum).

Many uncertainties in plankton biology could be addressed if samples for molecular genetic analysis could be obtained simply over large spatial scales. For example, Bucklin et al. (1998) have used DNA sequence variation to identify species of Pseudocalanus. The Continuous Plankton Recorder invented by Alister Hardy (Hardy, 1926) samples the open-ocean plankton over large spatial scales. The CPR survey Hardy established in 1931 has, with the exception of the Second World War, now operated every month of the year in the North Sea, since 1947 in the North Atlantic, and more recently in the North Pacific. A sister survey using similar equipment and methods operates in the South Atlantic, south and south-west of Australia (Hosie et al., 2003).

The CPR in the northern hemisphere has now sampled more than 5 million nautical miles of tow-route. The data collected by the CPR has helped understand the influence of latitudinal gradients and the position of current systems on the distributions of planktonic 
species on broad geographic scales (Beaugrand et al., 2001). Recently, GPR data has demonstrated shifts in the distributions of species at a scale of $10^{\circ}$ latitude in 40 years that appear to reflect global climate change (Reid et al., 2001; Beaugrand et al., 2002). These changes in plankton community structure have major impacts on the functioning of ecosystems (Beaugrand et al., 2003).

Molecular genetic methods in collaboration with CPR sampling could make a large advance in plankton ecology. There are also unique problems associated with CPR samples that molecular methods could resolve to improve studies of community ecology. For example, the taxonomic resolution of analysis is limited by the sampling method and the time and expert-

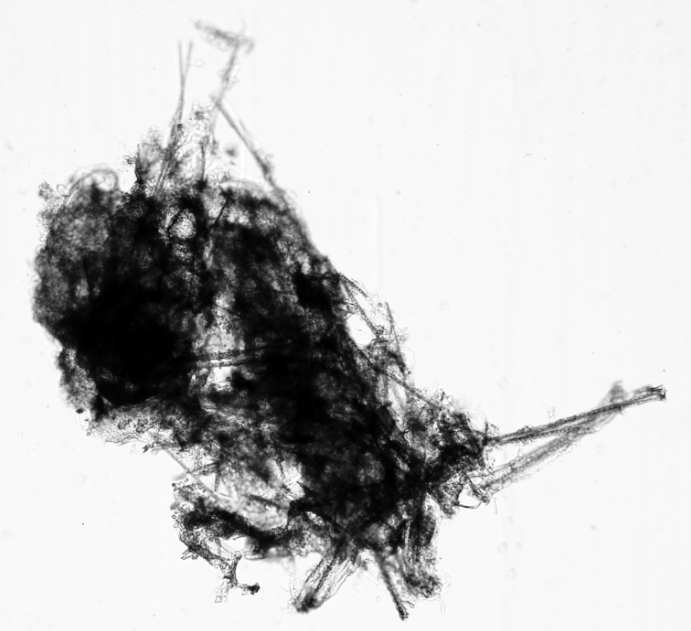

\section{$0.5 \mathrm{~mm}$}

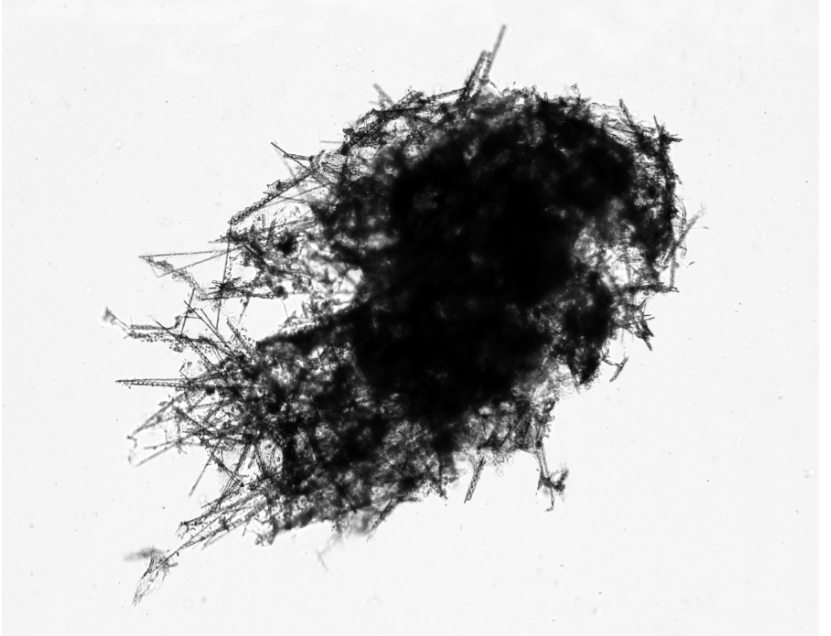

Figure 1. Two examples of typical echinoderm larvae (Echinoidea, putatively E. cordatum) sampled by the CPR and taken from the silk for molecular analysis in this study. Planktonic organisms sampled by the CPR are sandwiched between two layers of $270 \mathrm{~nm}$ silk mesh that is wound into a tank of formalin. This leads to the organisms being flattened with a loss of morphological characters. ise required for sample analysis. Firstly, plankton collected by the CPR are often damaged during sampling so that specific morphological features are lost (Figure 1). Secondly, in many cases the morphological criteria used for identification of the adult holoplankton (taxa that spend their whole life cycle in the plankton) require such detailed examination and careful measurement (e.g. Frost, 1989) that it is beyond the scope of the time available in ecological survey work; accurate identification of juvenile stages is even more problematic.

The application of molecular biology methods to CPR samples has been hindered until now by the sampling method that involves preservation in formalin. We have therefore investigated the application of different molecular genetic methods to obtain DNA from formalin-fixed CPR samples (Kirby \& Reid, 2000). The mode of action of formalin on amine groups and the reversible fixation of nucleic acids is now understood well (Masuda et al., 1999; Shi et al., 2002). Here, a simple method developed to extract DNA from formalin-fixed CPR samples to assist the study of plankton biology is presented in an analysis of echinoderm larvae sampled by the CPR in the North Sea.

The plankton community of the North Sea is changing (Beaugrand et al., 2003). It is important to understand the biology of North Sea echinoderms in particular due to a recent dramatic increase in their planktonic larvae in CPR samples, in both relative and absolute abundance (Lindley et al., 1995; Lindley \& Batten, 2002). Also, there has been a shift in the timing resulting in earlier occurrence of the larvae in the seasonal cycle (Greve et al., 2001). Figure 2 shows the annual mean numbers of echinoderm larvae and post larvae per sample in a consistently well sampled area of the North Sea bounded by $55^{\circ} \mathrm{N}, 56^{\circ} \mathrm{N}, 1^{\circ} \mathrm{W}$ and $5^{\circ} \mathrm{E}$ (shown as a shaded box in Figure 3). Previously, the only work in which echinoderm larvae from the North Sea have been identified from CPR material was by Rees (1954). His results showed that Echinocardium cordatum was the most abundant species with Ophiura albida, E. flavescens and Amphiura spp. also constituting a substantial proportion of the larvae in the samples. One possible explanation for the increase and change of timing in echinoderm larvae is a change in species composition, perhaps due either to an invasion or an increase in abundance of a previously rare species. Since benthic surveys in the North Sea have recorded an increase in abundance of A. filiformis (Kröncke, 1992; Buchanan, 1993; Josefson et al., 1993) Lindley et al., (1995) suggested that this species might be responsible. However, Kröncke et al., (1998), showed E. cordatum increased in abundance following mild winters. Lindley \& Batten 


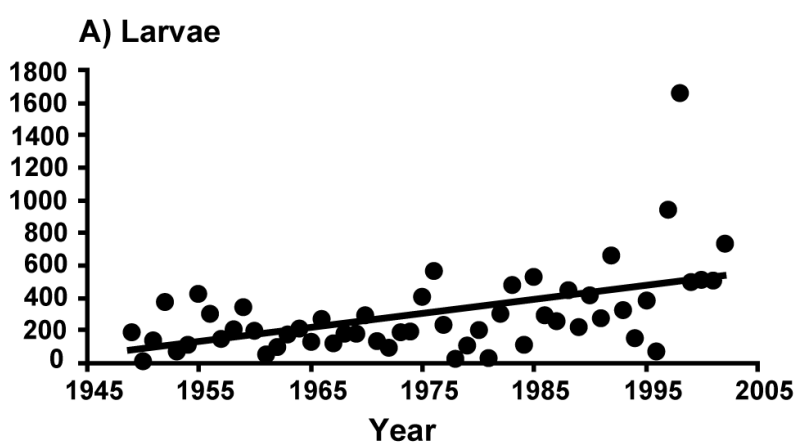

B) Post-larvae

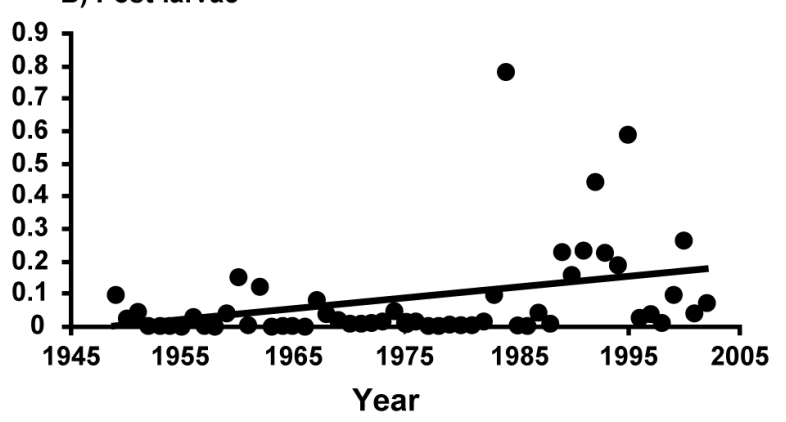

Figure 2. Echinodermata. (A) Larvae and (B) post-larvae. Annual mean number per CPR sample in area indicated by the stippled box in Figure 3 .

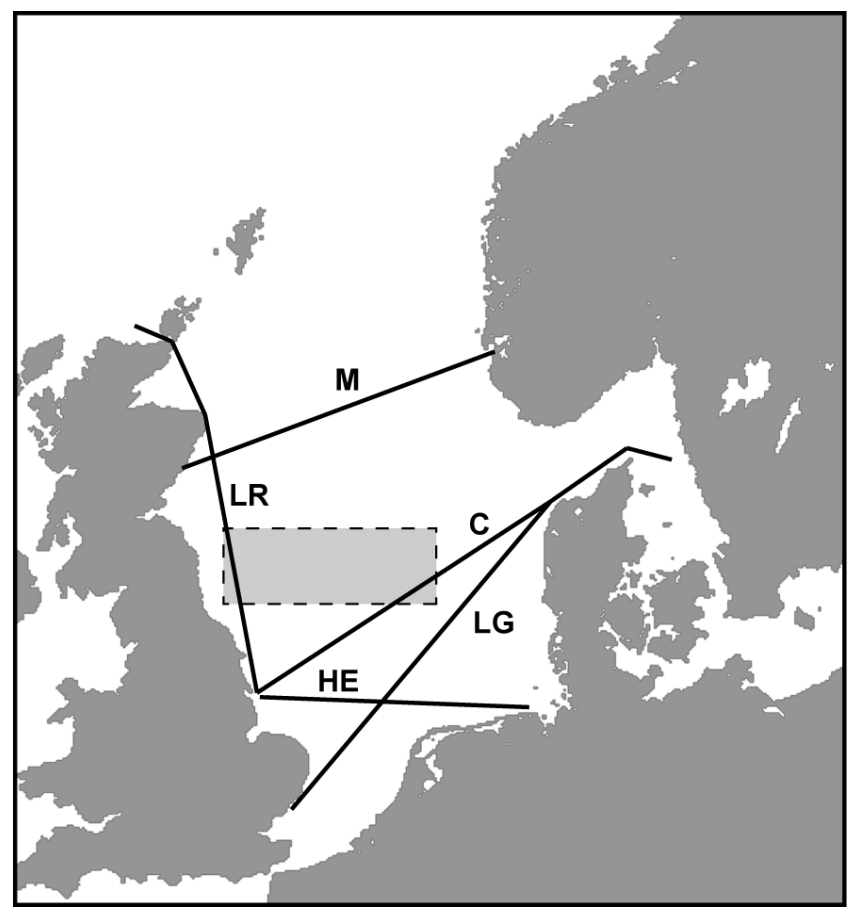

Figure 3. CPR tow-routes in the North Sea and adjacent areas in 2003. Routes from which material were taken in this study are identified by code letters. The shaded box is the area for which data are presented in Figure 2.
(2002) therefore suggested that this species could be responsible, due to the recent warming of the North Sea and relatively mild winters since 1987, which have also been implicated in a broader regime shift in community composition in this region (Reid et al., 2001).

There are a variety of larval forms of echinoderms and entirely gelatinous forms cannot be recognized in CPR samples, so only the pluteus larvae of ophiuroids and echinoids, which have calcareous skeletal rods, are counted. The lack of comprehensive descriptions of echinoderm larvae, the incomplete key to ophioplutei and echinoplutei by Geiger (1964) is the only guide available for North Sea taxa, and the damage often sustained by larvae when sampled by the CPR hinder their identification in CPR samples. Furthermore, post-larval bodies that develop attached to pelagic larvae or occur after the residual larval tissues have been discarded are only recorded in CPR samples as 'echinoderm post-larvae' since there is no available literature on how to identify them at this stage. To help resolve some of these issues we have applied the new molecular approaches described here to the identification of the larvae and post-larvae of echinoderms in North Sea CPR samples.

\section{MATERIALS AND METHODS CPR sampling}

The GPR is towed in the water at $\sim 6.5 \mathrm{~m}$ depth by merchant ships on their normal trading routes at speeds between $10 \mathrm{kn}\left(18 \mathrm{~km} \mathrm{~h}^{-1}\right)$ and $20 \mathrm{kn}\left(36 \mathrm{~km} \mathrm{~h}^{-1}\right)$. Seawater enters the CPR through a small front aperture $\left(1.27 \mathrm{~cm}^{2}\right)$ and the plankton is filtered onto a moving silk mesh that is slowly wound into a tank of formalin; 6 metres of silk represents 500 nautical miles of tow. The tow routes in the North Sea and adjacent areas in 2003 are shown in Figure 3. In the laboratory, the silk mesh is cut into sections each representing the plankton from $3 \mathrm{~m}^{3}$ of water taken during 10 nautical miles $(18 \mathrm{~km})$ of tow; alternate samples are distributed to a team of analysts who count and identify the plankton visually. Currently, up to 450 planktonic taxa are identified and counted in the CPR survey (Batten et al., 2003).

\section{Sample collections}

Adult representatives of 27 of the most common benthic Echinodermata found in the North Sea were collected from the North Sea, the English Channel and the Irish Sea between July and October 2001 by benthic trawling and subsequently frozen or preserved in ethanol. Details of these surveys are given by Ellis \& Rogers (2000) and Callaway et al., (2002). The echinoderm taxa studied and sample locations are given in Table 1. 
Table 1. Sample locations of the adult echinoderms studied together with the Genbank accession numbers for their partial $m t D N A$ 16S rRNA sequences.

\begin{tabular}{lcc}
\hline Taxa & Sample & GenBank \\
location & Reference no. \\
\hline Luidia sarsi & Irish Sea & AY652495 \\
Luidia ciliaris & Irish Sea & AY652496 \\
Solaster endeca & Irish Sea & AY652497 \\
Crossaster papposus & Irish Sea & AY652498 \\
Henricia sanguinolenta & Irish Sea & AY652499 \\
Henricia oculata & Irish Sea & AY652500 \\
Astropecten irregularis & Irish Sea & AY652501 \\
Anseropoda placenta & Irish Sea & AY652502 \\
Porania pulvillus & Irish Sea & AY652503 \\
Asterias rubens & English Channel & AY652504 \\
Leptasterias muelleri & Irish Sea & AY652505 \\
Marthasterias glacialis & Irish Sea & AY652506 \\
Ophiura albida & English Channel & AY652507 \\
Ophiura ophiura & English Channel & AY652508 \\
Amphiura filiformis & North Sea & AY652509 \\
Amphiura squamata & North Sea & AY652510 \\
Amphipholis chiajei & English Channel & AY652511 \\
Ophiothrix fragilis & North Sea & AY652512 \\
Ophiopholis aculeata & North Sea & AY652513 \\
Strongylocentrotus droebachiensis & North Sea & AY652514 \\
Echinus esculentus & Irish Sea & AY652515 \\
Psammechinus miliaris & North Sea & AY652516 \\
Spatangus purpureus & North Sea & AY652517 \\
Echinocardium cordatum & North Sea & AY652518 \\
Echinocardium flavescens & North Sea & AY652519 \\
Brissopsis lyrifera & North Sea & AY652520 \\
Antedon bifida & Irish Sea & AY652521 \\
\hline & & \\
\hline & &
\end{tabular}

Echinoderm larvae were sampled in the North Sea by the CPR on tow-routes between $53^{\circ} \mathrm{N}$ and $58^{\circ} \mathrm{N}$ and $0^{\circ}$ and $7^{\circ} \mathrm{E}$. In this study, the pluteus larvae in a sub-sample of $2 \%$ and the total number of echinoderm post-larvae (Batten et al., 2003) were counted in samples collected in June and July 2003. After tentative morphological identification, 94 individual larvae were removed from the silk over the region of the tow-route by using a needle. Each larva was then transferred into a separate $1.5 \mathrm{ml}$ Cap-Lok microcentrifuge tube (Robbins Scientific) each containing $25 \mu \mathrm{l}$ of sterile water. Tubes and larvae were stored at $-70^{\circ} \mathrm{C}$ prior to DNA extraction. To check that the selection of larval material had not been biased, a sub-sample of 25 specimens were identified from each of four samples on which larvae had been recorded as abundant after the results of the molecular analyses were available.

\section{DNA extraction from adult echinoderms}

DNA was extracted by the method of Boom et al., (1990) from a small piece of tissue, either a few tube feet, a piece of epidermis or a small piece of gonad. DNA was resuspended in $50 \mu \mathrm{l}$ sterile water and stored at $-70^{\circ} \mathrm{C}$.

\section{$D N A$ extraction from formalin-fixed CPR samples}

DNA was extracted from 35 of the 94 individual echinoderm larvae sampled from the CPR silk; this subset was selected randomly. Table 2 gives the geographical locations from which the larvae were sampled. DNA extraction methods used principles of the antigen retrieval technique (hydrolysis, alkali conditions and high temperatures) as applied to formalinfixed material (Shi et al., 2002) to break methylene bridges and remove methylol groups. Each larva was defrosted and $175 \mu \mathrm{l}$ of Chelex solution $(\mathrm{pH} \sim 9.0)$ was added (Instagene Matrix, Biorad) together with $7 \mu \mathrm{l}$ of 1M Dithiothreitol (DTT), $4 \mu \mathrm{l}$ of proteinase-K solution $(10 \mathrm{mg} / \mathrm{ml})$ and $5 \mu \mathrm{l}$ of a detergent solution $(10 \%$ Triton X-100 and 10\% Tween 20) (since development of the protocol used in this study we now substitute $5 \mu \mathrm{l}$ of $10 \%$ SDS for the Triton X-100/Tween 20 detergent mix. A total of $5 \mu \mathrm{l}$ of $0.5 \%$ PVPP (Polyvinylpolypyrrolidone) can also be added if the sample is high in phenolic compounds). The larva and extraction solution were then incubated at $55^{\circ} \mathrm{C}$ for $4 \mathrm{~h}$ with gentle agitation at hourly intervals (this incubation time can be shortened if the sample permits). Each larva was then vortexed briefly and centrifuged at $12,000 \mathrm{~g}$ for $15 \mathrm{~s}$ at room temperature in a Beckman 'Avanti 30' centrifuge fitted with rotor F2402H. Samples were then heated at $105^{\circ} \mathrm{C}$ for $10 \mathrm{~min}$ in a dry-block heater. The sample was then vortexed for $10 \mathrm{~s}$ and centrifuged at $12,000 \mathrm{~g}$ for $3 \mathrm{~min}$. The supernatant was then transferred to a Micropure-EZ centrifugal filter device (CFD) (Millipore Corp.) that was inserted into a Microcon YM-30 CFD (Millipore Corp.) to form a combined unit according to the manufacturer's instructions. The sample was then centrifuged at $14,000 \mathrm{~g}$ for $8 \mathrm{~min}$. The Micropure-EZ CFD was then discarded and the sample retained by the YM-30 was washed three times by adding $200 \mu \mathrm{l}$ of sterile water; the first two washes were each centrifuged at $14,000 \mathrm{~g}$ for $8 \mathrm{~min}$ and the final wash was centrifuged at 14,000g for $5 \mathrm{~min}$ (when using SDS as the detergent we omit one of the first two wash steps without deleterious effects). The DNA retained by the YM-30 membrane was recovered finally according to manufacturer's instructions; the typical retentate volume from echinoderm larvae was between 10 and $15 \mu$. All centrifugation steps were performed at room temperature $\left(22^{\circ} \mathrm{C}\right)$. 
Table 2. Sample identifications, latitudes, longitudes and dates of sampling for echinoderm larvae analysed using molecular methods.

\begin{tabular}{lllll}
\hline & & & & Specimen \\
Sample ID & Latitude & Longitude & Date & ID \\
\hline 230LG14 & $53^{\circ} 59.8^{\prime} \mathrm{N}$ & $05^{\circ} 13.1^{\prime} \mathrm{E}$ & $14 / 06 / 03$ & $\mathrm{~N} 43$ \\
210HE12 & $53^{\circ} 58.8^{\prime} \mathrm{N}$ & $03^{\circ} 41.1^{\prime} \mathrm{E}$ & $14 / 06 / 03$ & $\mathrm{~N} 103-\mathrm{N} 107$, \\
& & & N110, N111 \\
210HE16 & $54^{\circ} 1.5^{\prime} \mathrm{N}$ & $04^{\circ} 48.0^{\prime} \mathrm{E}$ & $14 / 06 / 03$ & $\mathrm{~N} 78, \mathrm{~N} 82$, \\
& & & N84, N86- \\
& & & $\mathrm{N} 90, \mathrm{~N} 99$ \\
292M-26 & $58^{\circ} 50.5^{\prime} \mathrm{N}$ & $05^{\circ} 48.4^{\prime} \mathrm{E}$ & $30 / 06 / 03$ & $\mathrm{~N} 116-\mathrm{N} 119$ \\
274LR28 & $55^{\circ} 36^{\prime} \mathrm{N}$ & $00^{\circ} 29^{\prime} \mathrm{W}$ & $04 / 07 / 03$ & $\mathrm{~N} 126$ \\
231LG12 & $53^{\circ} 42.8^{\prime} \mathrm{N}$ & $04^{\circ} 59.0^{\circ} \mathrm{E}$ & $16 / 07 / 03$ & $\mathrm{~N} 23$ \\
$605 \mathrm{C} 16$ & $55^{\circ} 36.0^{\prime} \mathrm{N}$ & $04^{\circ} 48.8^{\prime} \mathrm{E}$ & $07 / 07 / 03$ & $\mathrm{~N} 42$ \\
\hline
\end{tabular}

\section{DNA amplification and sequencing}

A partial 3' mtDNA $16 S$ rRNA gene sequence was amplified from $1 \mu \mathrm{l}$ of adult echinoderm template DNA using $10 \mathrm{pmol}$ each of modified versions of the 'universal' mtDNA $16 S$ rRNA gene primers 5'-CGGCTCTTTATCAAAAACAW-3' (forward) and 5'-CGGGTGTGAATGTAGATCR-3' (reverse) (Palumbi et al., 1991) and a proof reading polymerase (Pfu, Stratagene). The thermal PCR profile involved an initial denaturation at $94^{\circ} \mathrm{C}$ for $3 \mathrm{~min}$ followed by 30 cycles of $94^{\circ} \mathrm{C}$ for $1 \mathrm{~min}, 54^{\circ} \mathrm{C}$ for $20 \mathrm{~s}$ and $72^{\circ} \mathrm{C}$ for $1 \mathrm{~min} 30 \mathrm{~s}$ and a final extension of 20 min to insure PCR fragments were full-length. The PCR products were blunt-end cloned and then sequenced using an automated DNA sequencer.

For the formalin-fixed pluteus larvae from the CPR, a partial mtDNA $16 S r R N A$ gene sequence was amplified from $1 \mu \mathrm{l}$ of template DNA by two-step nested PCR using Taq DNA polymerase (Invitrogen). Firstround PCR primers and thermal cycle parameters were the same as those used for the adult echinoderms except that 35 PCR cycles were performed and the extension time was reduced to 45 seconds. The second-round nested PCR used $1 \mu \mathrm{l}$ of the first-round PCR product as template and 10 pmol each of the 'echinoderm specific' PCR primers 5'-GGCTGTTTACGAAAAACAWCG-3' (forward) and 5'-GATGCAACATGTAGGTCGG-3' (reverse), which were designed from the adult DNA sequences obtained above. These primers differentiated at their 3'-base between the mtDNA 16s $r R N A$ gene sequence of the 27 adult echinoderm taxa studied above and that of the Homo sapiens mtDNA $16 S$ rRNA gene (GenBank accession number, AY570526). These nested primers amplify a 449-568 bp partial 3' mtDNA $16 S$ rRNA gene sequence according to the individual echino- derm taxon. Thermal cycle parameters were similar to the first-round except for the annealing temperature, which was raised to $57^{\circ} \mathrm{C}$. No template negative controls were run at all times. Amplification products were purified (QIAquick, Qiagen) and sequenced using the second-round forward PCR primer as the sequencing primer.

\section{DNA Sequence and taxonomic analysis}

Partial mtDNA $16 S r R N A$ gene sequences of adult echinoderms were aligned using the profile alignment option in Clustal W (Thompson et al., 1994). The alignment was adjusted manually where necessary and a phylogenetic tree was constructed by neighbour joining on Jukes-Cantor distances using the computer program MEGA (Kumar et al., 2001). The identity of the echinoderm larvae was determined simply by comparing the partial nested mtDNA 16s $r R N A$ larval gene sequences by alignment to the mtDNA $16 s r R N A$ gene sequences obtained from the adults.

\section{RESULTS}

Table 1 provides the GenBank accession numbers of the partial (531-650 bp according to the taxa) mtDNA $16 S$ rRNA gene sequences obtained from the adult echinoderms. Figure 4 shows the phylogenetic relationships among this sample of echinoderms based upon these partial gene sequences. The relationships among the taxa conform to those expected on morphological criteria (Janies, 2001).

Figure 1 shows typical examples of the echinoderm material sampled from the CPR silk. A total of 90 of the 94 larvae retrieved from the CPR silk were identified tentatively as spatangoid Echinoidea and puta-

Table 3. Provisional visual identification from morphology of larval echinoderms and their identity from molecular analysis.

\begin{tabular}{|c|c|c|}
\hline \multicolumn{3}{|c|}{ Provisional visual } \\
\hline Sample ID & ID & Molecular ID \\
\hline 230LG14 & E. cordatum $(1)$ & M. glacialis (1) \\
\hline \multirow[t]{3}{*}{ 210HE12 } & E. cordatum $(7)$ & E. cordatum (5) \\
\hline & & S. purpureus (1) \\
\hline & & M. glacialis (1) \\
\hline 210HE16 & E. cordatum (9) & E. cordatum $(9)$ \\
\hline \multirow[t]{2}{*}{ 292M-26 } & Ophiuroid (3) & A. filiformis (3) \\
\hline & E. cordatum $(1)$ & \\
\hline 274LR28 & Ophiuroid (1) & M. glacialis (1) \\
\hline 231LG12 & E. cordatum $(1)$ & E. cordatum (1) \\
\hline $605 \mathrm{C} 16$ & E. cordatum (1) & E. cordatum (1) \\
\hline
\end{tabular}


Table 4. Visual identities of 25 specimens from each of four samples in which echinoderm larvae were recorded as abundant. (No. per sample $=$ accepted value of number of echinoderm larvae per sample from original analysis of sub-sample).

\begin{tabular}{cccccc}
\hline Sample ID & Latitude & Longitude & Date & No. per sample & $\begin{array}{c}\text { Identity of } 25 \\
\text { specimen }\end{array}$ \\
\hline 209 HE25 & $54^{\circ} 00.8^{\prime} \mathrm{N}$ & $07^{\circ} 31.3^{\prime} \mathrm{E}$ & $10 / 05 / 03$ & 3750 & $\begin{array}{c}\text { E. cordatum }(19) \\
\text { O. textura }(1) \\
\text { O. albida }(4) \\
\text { E. cordatum }(23) \\
\text { O. textura }(1)\end{array}$ \\
473LR21 & $56^{\circ} 18.5^{\prime} \mathrm{N}$ & $01^{\circ} 01.3^{\prime} \mathrm{W}$ & $06 / 06 / 03$ & 850 & $\begin{array}{c}\text { Amphiura sp. }(1) \\
\text { E. cordatum }(25)\end{array}$ \\
$605-13$ & $53^{\circ} 59.7^{\prime} \mathrm{N}$ & $03^{\circ} 57.9^{\prime} \mathrm{E}$ & $14 / 06 / 03$ & 300 & \begin{tabular}{c} 
E. cordatum $(25)$ \\
\hline
\end{tabular} \\
\hline
\end{tabular}

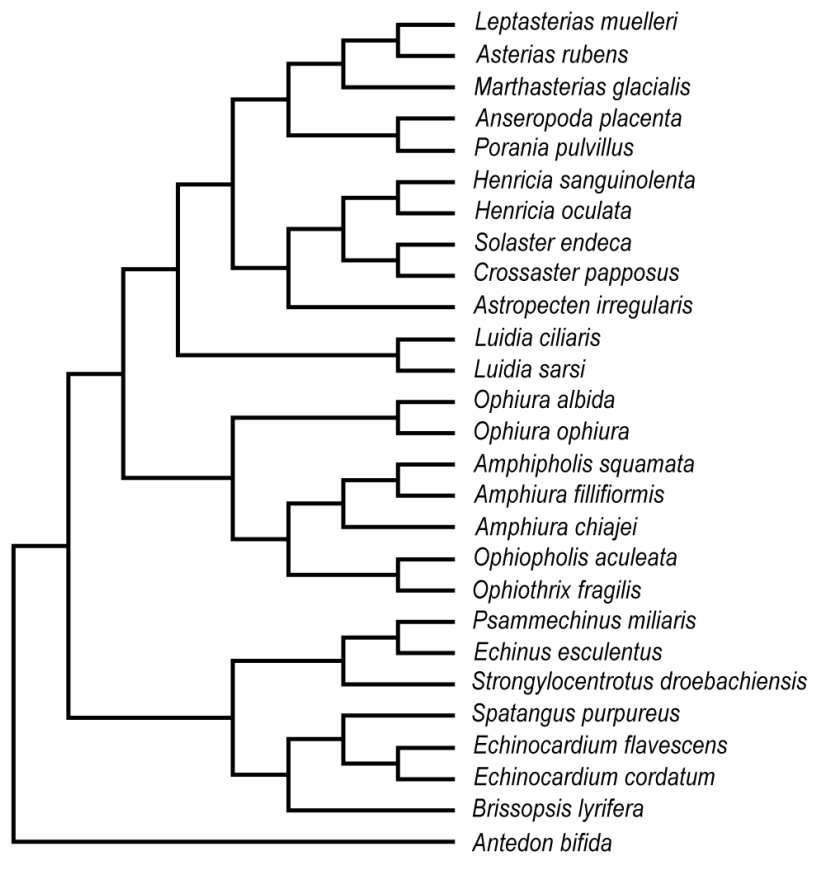

Figure 4. Phylogenetic relationships among the benthic echinoderms examined in this study based upon their partial mtDNA $16 S \mathrm{rRNA}$ gene sequences. The tree was constructed by neighbour joining on Jukes-Cantor distances. The DNA sequence of the crinoid, Antedon. bifida was used to root the tree.

tively as Echinocardium cordatum based upon their remaining morphological features. The remaining four larvae were classified as unidentified members of the Ophiuroidea. The 35 larvae from which DNA was extracted comprised 31 of the Echinoidea and the 4 Ophiuroidea that were sampled. A total of 28 of the 35 DNA extractions yielded second-round amplification products (first-round amplifications were all visible but faint in most cases when viewed by agarose gel electrophoresis and stained with SYBR green-1); these comprised 24 of the putative Echinoidea and the four Ophiuroidea. A total of 24 of the 28 second-round amplifications were identified as partial sequences similar to the mtDNA $16 S$ rRNA gene of the Echinodermata; the remaining sequences were similar to the Homo sapiens mtDNA $16 S$ rRNA gene. Table 3 shows the provisional identity of the echinoderm larvae based upon morphological criteria and their identification based upon the subsequent molecular analysis. Among the 24 larval mtDNA $16 S$ rRNA gene sequences obtained, 18 were similar to the Echinoidea (17 were similar to E. cordatum and one was similar to Spatangus purpureus), three were similar to Amphiuma filiformis (Ophiuroidea) and three were similar to Marthasterias glacialis (Asteroidea).

Table 4 shows the identity of 25 specimens in each of four samples where echinoderm larvae were recorded as abundant using morphological criteria. In these four samples $92 \%$ were identified as belonging to the Echinoidea (these were all identified as E. cordatum) and $8 \%$ as various members of the Ophiuroidea.

\section{DISGUSSION}

The molecular methods developed for the study of formalin-fixed CPR samples yielded DNA from which a 449-650 bp product could be amplified reliably from $63 \%$ of the formalin-fixed echinoderm larvae sampled. The method is relatively inexpensive costing approximately $£^{2.50}$ per sample, which is comparable to other DNA extraction methods. The success rate is similar to other molecular studies of formalin-fixed material (France \& Kocher, 1996; Wirgin et al., 1997; Coombs et al., 1999). Our extraction methods have the advantage, however, in that they may be completed in a single tube without the need for lengthy overnight proteinase-K incubations or DNA precipitation steps common to other methods (Bucklin \& Allen, 2004). The complete process from DNA extraction to second round PCR product may be completed in a single day by an experienced technician and rapid thermal-cycler. Our methods provide sufficient high 
molecular weight template DNA (as visualized by agarose gel electrophoresis), frequently from very small amounts of poor quality larval tissue, to enable PCR amplification of useful DNA sequences. The appearance of Homo sapiens sequences in this study is not uncommon in our analyses of formalin-preserved CPR material when we use universal mtDNA $16 S$ $r R N A$ gene primers. We are unsure exactly when this contamination occurs. The CPR silk is handled considerably during its preparation. Formalin-fixed template DNA is also likely to be of poorer quality than human DNA, which might be introduced either at DNA extraction or during subsequent molecular analysis. Contamination with human DNA is not a problem when species-specific primers are used to amplify DNA from CPR samples (R.R.K., personal observations).

We chose to study echinoderm larvae in the North Sea in this first application of molecular methods to CPR samples for two principal reasons. Firstly, it has become important to resolve which echinoderm larvae dominate the North Sea plankton to understand the changing ecology of this region. Secondly, although the condition of echinoderm larvae on CPR silks makes their unequivocal identification problematic, taxa such as larval Echinoidea that, on occasions, can dominate the plankton, may be determined tentatively using morphological criteria and this provided a useful comparison to the molecular analyses. This was considered important in order to determine whether neighbouring specimens on the silk of different taxa might be a confounding influence. Apart from the $H$. sapiens sequences obtained, no sequences were obtained from taxa other than Echinodermata. This concurs with more preliminary studies we have conducted on fish larvae (Kirby \& Reid, 2000) and copepods (unpublished data) that have used only the universal mtDNA $16 S r R N A$ gene PGR primers $16 \mathrm{SAR}-\mathrm{L}$ and 16SBR-H (Palumbi et al., 1991). On all occasions so far the correct taxonomic gene sequence of the target organism has been obtained on each occasion.

The mismatches in this study between the initial provisional identifications and the results of the molecular analyses can, in most cases, be attributed to misidentification in the original sorting. Spatangus purpureus and Echinocardium cordatum are both spatangoids with scalariform postero-dorsal, postoral and posterior skeletal rods and the extent of damage during collection by the CPR could impede accurate discrimination between these closely related species. The post-larvae of Marthasterias glacialis are very spinose and could be mistaken for post-larval Ophiuroidea but the most likely explanation for the records of $M$. glacialis is that the soft larval tissue of the latter was entangled with the identified specimens and masked their DNA; Figure 1 shows typical examples of CPR echinoderm samples and demonstrates how such contamination could be overlooked.

This study confirms that the Echinoidea dominating the North Sea plankton CPR samples in both biomass and numerical abundance are E. cordatum. The dominance of this species indicates that the changes in abundance of echinoderm larvae in CPR records in the North Sea are due to changes in long well-established populations, not invasions or previously rare species becoming dominant. Rees (1954) recorded Amphiura spp. larvae widely and as particularly abundant north of the Dogger Bank, but was unable to refer them to species. Although there were few Amphiura that could be sampled free of contaminating material, we have been able to identify the specimens examined here as A. filiformis. Spatangus purpureus was widespread in Rees' (1954) samples but an order of magnitude less abundant than E. cordatum.

The recorded northern Atlantic distribution of $M$. glacialis is extensive along the eastern coasts from Finmark to Bohuslan (West Sweden) in Scandinavia and around the north and west of the British Isles (Clark \& Downey, 1992, pp. 443-445). The locations where $M$. glacialis was recorded in this study are in regions of inflow, from the English Channel in the cases of 210HE12 and 230LG14 and in the case of sample 274LR28, in the southward flowing water originating from north and west of Scotland and therefore agree with where this species might be expected to occur in the plankton. The appearance of M. glacialis in this study is important for two reasons. Firstly it shows that a molecular approach can identify gelatinous organisms that are damaged beyond recognition during sampling and preservation in the CPR. Secondly, the presence of this species in three locations indicates that these larvae may be present in the North Sea plankton when the adults are not normally considered particularly common within the central North Sea region from where these CPR tows were taken.

The GPR has contributed enormously to our understanding of marine ecosystems and the data collected has shown important changes in plankton communities (Beaugrand et al., 2002). Here we have shown by molecular analysis that larvae of a particular species that favours mild winters have increased in abundance in the North Sea in agreement with the general regime shift in community structure in this region that is attributed to global warming (Reid et al., 2001; Beaugrand et al., 2002). Formalin was chosen as the method of preservation of CPR samples long before molecular methods enabled the study of genetic vari- 
ation. Since all CPR samples are still preserved in formalin for continuity of analysis, the molecular methods described here will enable CPR samples to address many unresolved questions in plankton ecology. For example, the unique ability of the CPR to sample the plankton over large spatial scales and from remote locations will permit the population structure in the open-ocean plankton to be studied over appropriate scales.

This work was funded by the Natural Environment Research Council of the UK and the Royal Society. We would like to thank the owners, masters and crews of the ships that tow CPRs and scientists R. Callaway, T. Dinmore and J. Ellis (CEFAS) for collecting adult echinoderms during groundfish surveys of RV 'Cirolana' and RV 'Corystes'.

\section{REFERENCES}

Batten, S.D. et al., 2003. CPR sampling: the technical background, materials and methods, and issues of consistency and comparability. Progress in Oceanography, 58, 193-215.

Beaugrand, G., Ibañez, F. \& Reid, P.C., 2001. Geographical distribution and seasonal and diel changes in the diversity of calanoid copepods in the North Atlantic and North Sea. Marine Ecology Progress Series, 219, 189-203.

Beaugrand, G., Brande, K.M., Lindley, J.A., Souissi, S. \& Reid, P.C., 2003. Plankton effect on cod recruitment in the North Sea. Nature, London, 426, 661-664.

Beaugrand, G., Reid, P.C., Ibañez, F., Lindley, J.A. \& Edwards, M., 2002. Reorganization of Atlantic marine copepod biodiversity and climate. Science, New York, 296, 1692-1694.

Boom, R., Sol, G.J.A., Salimans, M.M.M., Jansen, G.l., Wertheim-Van Dillen, P.M.E. \& Van der Noordaa, J., 1990. Rapid and simple method for purification of nucleic acids. Fournal of Clinical Microbiology, 28, 495-503.

Buchanan, J.B., 1993. Evidence of benthic pelagic coupling at a station off the Northumberland coast. Fournal of Experimental Marine Biology and Ecology, 172, 1-10.

Bucklin, A. \& Allen, L.D., 2004. MtDNA sequencing from zooplankton after long-term preservation in buffered formalin. Molecular Phylogenetics and Evolution, 30, 879-882.

Bucklin, A., Bentley, A.M. \& Franzen, S.P., 1998. Distribution and relative abundance of Pseudocalanus moultoni and P. newmani (Copepoda: Calanoida) on Georges Bank using molecular identification of sibling species. Marine Biology, 132, 97-106.

Callaway, R. et al., 2002. Diversity and community structure of epibenthic invertebrates and fish in the North Sea. ICES Journal of Marine Science, 59, 1199-1214.

Caudill, C.C. \& Bucklin, A., 2004. Molecular phylogeography and evolutionary history of the estuarine copepod, Acartia tonsa, on the Northwest Atlantic coast. Hydrobiologia, 511, 91-102.

Clark, A.M. \& Downey, M.E., 1992. Starfishes of the Atlantic. London: Chapman and Hall.
Clark, P.F., 1984. A comparative study of zoeal morphology in the genus Liocarcinus (Crustacea: Brachyura: Portunidae). Zoological Fournal of the Linneaen Society, 82, 219-254.

Coombs, N.J., Gough, A.C. \& Primrose, J.N., 1999. Optimisation of DNA and RNA extraction from archival formalin-fixed tissue. Nucleic Acids Research, 27, e12, i-iii.

Ellis, J.R. \& Rogers, S.I., 2000. The distribution, relative abundance and diversity of echinoderms in the eastern English Channel, Bristol Channel and Irish Sea. Fournal of the Marine Biological Association of the United Kingdom, 80,127-138.

France, S.C. \& Kocher, T.D., 1996. DNA sequencing of formalin-fixed crustaceans from archival research collections. Molecular Marine Biology and Biotechnology, 5, 304-313.

Frost, B.W., 1989. A taxonomy of the marine calanoid copepod genus Pseudocalanus. Canadian Fournal of Zoology, 67, 525-551.

Geiger, S.R., 1964. Echinodermata: larvae. Classes Ophiuroidea and Echinoidea. Fiches d'Identification $d u$ Zooplankton, 105, 1-5.

Greve, W., Lange, U., Reiners, F. \& Nast, J., 2001. Predicting the seasonality of North Sea zooplankton. Senckenbergiana Maritima, 31, 263-268.

Hardy, A.C., 1926. The herring in relation to its animate environment. Pt. II. Report on trials with the Plankton Indicator. Fisheries Investigations, Ser II, 8, p. 13.

Hosie, G.W., Fukuchi, M. \& Kawaguchi, S., 2003. Development of the Southern Ocean Continuous Plankton Recorder survey. Progress in Oceanography, 58, 263-283.

Janies, D., 2001. Phylogenetic relationships of extant echinoderm classes. Canadian fournal of Zoology, 79, 1232-1250.

Josefson, A.B., Jensen, J.N. \& Ertberg, G., 1993. The benthos community structure anomaly in the late 1970s and early 1980s - a result of a major food pulse. Fournal of Experimental Marine Biology and Ecology, 172, 31-45.

Kirby, R.R. \& Reid, P.C., 2001. PCR from the CPR offers a historical perspective on marine population ecology. Fournal of the Marine Biological Association of the United Kingdom, 81, 539-540.

Kröncke, I., 1992. Macrofauna standing stock of the Dogger Bank - a comparison. 3. 1950-54 versus 1985-87 - a final summary. Helgoländer Meeresuntersuchungen, 46, 137-169.

Kröncke, I., Dippner, J.W., Heyen, H. \& Zeiss, B., 1998. Long-term changes in macrofaunal communities off Norderney (East Frisia, Germany) in relation to climate variability. Marine Ecology Progress Series, 167, 25-36.

Kumar, S., Tamura, K., Jokobsen, I.B. \& Nei, M., 2001. MEGA2, Molecular Evolutionary Genetics Analysis software Tempe, Arizona, USA: Arizona State University.

Lee, C.E., 2000. Global phylogeography of a cryptic copepod species complex and reproductive islation between genetically proximate "populations". Evolution, 54, 2014-2027.

Lindley, J.A. \& Batten, S.D., 2002. Long-term variability in the diversity of North Sea zooplankton, Fournal of the Marine Biological Association of the United Kingdom, 82, 31-40. 
Lindley, J.A., Gamble, J.C. \& Hunt, H.G., 1995. A change in the zooplankton of the central North Sea $\left(55^{\circ}-58^{\circ} \mathrm{N}\right)$ : a possible consequence of changes in the benthos. Marine Ecology Progress Series, 119, 299-303.

Masuda, N., Ohnishi, T., Kawamoto, S., Monden, M. \& Okubo, K., 1999. Analysis of chemical modification of RNA from formalin-fixed samples and optimisation of molecular biology applications for such samples. Nucleic Acids Research, 27, 4436-4443.

Palumbi, S.R., Martin, A., Romano, S., McMillan, W.O., Stice, L. \& Grabowski, G., 1991. The simple fools guide to $P C R$, v 2. Honolulu, Hawaii: University of Hawaii Zoology Department.

Puls, A.L., 2001. Arthropoda: Decapoda. In Identification guide to larval marine invertebrates of the Pacific northwest (ed. A.L. Shanks), pp. 197-250. Corvallis: Oregon State University Press.

Rees, C.B., 1954. Continuous plankton records: the distribution of echinoderm and other larvae in the North Sea, 1947-51. Bulletin of Marine Ecology, 4, 47-67.

Reid, P.C., Borges, M. \& Svendsen, E., 2001. A regime shift in the North Sea circa 1988 linked to changes in the North Sea horse mackerel fishery. Fisheries Research, 50, 163-171.
Shi, S-R. et al., 2002. DNA extraction from archival formalin-fixed, paraffin-embedded tissue sections based on the antigen retrieval principle: heating under the influence of pH. Journal of Histochemistry and Cytochemistry, 50, 1005-1011.

Thompson, J.D., Higgins, D.G. \& Gibson, T.J., 1994. CLUSTAL W: improving the sensitivity of progressive multiple sequence alignment through sequence weighting, positions-specific gap penalties and weight matrix choice. Nucleic Acids Research, 22, 4673-4680.

Williamson, D.I., 1982. The larval characters of Dorhynchus thomsoni Thomson (Crustacea: Brachyura, Majoidea) and their evolution. Journal of Natural History, 16, 727-744.

Wirgin, I., Maceda, L., Stabile, J. \& Mesing, C., 1997. An evaluation of introgression of Atlantic coast striped bass mitochondrial DNA in a Gulf of Mexico population using formalin-preserved museum collections. Molecular Ecology, 6, 907-916.

Submitted 14 October 2004. Accepted 23 February 2005. 